\title{
Desconstrução do cristianismo: imperativo ontológico à experiência de Deus na pós-modernidade
}

\author{
Deconstruction of christianity: ontological imperative to the experience of \\ God in postmodernity
}

Cleusa Caldeira*

\begin{abstract}
Resumo
Com este texto perscruta-se a maneira como a razão secular contribuiu para pensar a experiência de Deus no contexto pós-cristão e pós-metafísico. Neste novo contexto, explicitam-se as principais contribuições do "niilismo místico" à possível experiência religiosa no marco de novas condições culturais. Fundamental será a assunção da desconstrução enquanto método do pensamento crítico. Segue-se o teólogo mexicano Carlos Mendoza Álvarez que, partindo da crítica pós-cristã aos sistemas de crença e de moral, propõe a superação dos obstáculos que impedem o acesso ao manancial divino e, consequentemente, a volta à coisa mesma da fé cristã. Nesse horizonte, emerge a desconstrução do cristianismo como um imperativo ontológico para superar a metafísica clássica e, consequentemente, ascender à metafísica do Ser Superessencial. Inserido, pois, em sua própria desconstrução, do cristianismo declosionado surge a fé niilista como uma potência da subjetividade, como o estágio que representa a passagem de mundo da crença para o mundo iconoclasta e apofático, isto é, o mundo da fé sem a idolatria do sujeito.
\end{abstract}

Palavras-chave: pós-modernidade; pós-cristão; pós-metafísico; experiência de Deus; cristianismo declosionado.

\begin{abstract}
With text examines the way secular reason has contributed to the thinking of God's experience in the postChristian and post-metaphysical context. In this new context, the main contributions of "mystical nihilism" to the possible religious experience in the context of new cultural conditions are made explicit. Fundamental will be the assumption of deconstruction as a method of critical thinking. The Mexican theologian, Carlos Mendoza Álvarez, who, starting from the post-Christian critique to the systems of belief and morals, proposes to overcome the obstacles that impede the access to the divine source and, consequently, the return to the very thing of the Christian faith. In this horizon, the deconstruction of Christianity emerges as an ontological imperative to overcome classical metaphysics and, consequently, to ascend to the metaphysics of the Being Superessential. Inserted, then, in its own deconstruction, from the dis-enclosure Christianity, emerges the nihilist faith as a power of subjectivity, it as the stage that represents the passage from the world of belief to the iconoclastic and apophatic world, that is, the world of faith without idolatry of the subject.
\end{abstract}

Keywords: postmodern; post-Christian; post-metaphysical; experience of God; Christianity disenclosure.

Artigo submetido em 28 de novembro de 2017 e aprovado em 28 de dezembro de 2018.

* Doutora em Teologia pela Faculdade Jesuíta de Filosofia e Teologia. Pós-doutoranda em Teologia pela Pontifícia Universidade Católica do Paraná. Bolsista PNPD/Capes. País de origem: Brasil. E-mail: cleucaldeira@gmail.com 


\section{Introdução}

A pós-modernidade também é conhecida como “cultura do fragmento" e do "ultrapassamento dos sistemas fechados", incluindo nesse rol a religião com seu modelo mitológico, autoritário e hierárquico. Neste novo contexto, emerge o "humanismo pós-cristão", no qual a força humanizadora do cristianismo se deve ao deslocamento do modelo apologético da cristandade a um paradigma hermenêutico de secularização. Nos últimos tempos, de fato, deu-se a maior das transições com a chegada do "modelo pragmático de pluralismo cultural y religioso" (MENDOZA, 2007C, p. 16).

Essa mudança epocal coincide com a transformação das sociedades industriais em sociedades de conhecimento. Percebe-se, com isso, uma mutação radical na percepção do real e uma nova forma de inteligência. Emerge, pois, uma grande ruptura cultural somente comparável àquela da passagem Idade da Pedra ao período Neolítico, conforme afirma o escritor Marià Corbí (1996). Ocorre a transição da razão analógica à razão digital, que viabiliza a pluridimensionalidade do real e põe em questão a univocidade do metarrelato unificador de sentido dos monoteísmos. Assim, uma nova interpretação tornou-se possível às tradicionais sociedades pós-industriais que rejeitam os sistemas de crenças e de moral. Essas sociedades do conhecimento buscam distinguir a experiência religiosa da dinâmica colonialista que caracterizou a prática religiosa por séculos na história do Ocidente (MENDOZA, 2010, p. 65). Em outras palavras, seguindo a filosofia da religião pósmoderna, a experiência religiosa na pós-modernidade se vincula intrinsecamente ao evento da subjetividade, de maneira que não é possível conceber a humanidade fora do terreno na qual se dá a religação com o outro e com a transcendência. Partindo dessa premissa, o teólogo mexicano Carlos Mendoza Álvarez ${ }^{1}$ chama a atenção para o retorno do religioso enquanto autêntico sinal dos tempos, como sinal do reencantamento da cultura. Mais que um fenômeno típico de um sujeito

\footnotetext{
${ }^{1}$ Nascido em Puebla em 24 de abril de 1961, México, o frei dominicano Carlos Mendoza Álvarez é considerado o maior expoente da teologia da libertação em contexto pós-moderno. Autor de dezenas de livros e uma centena de artigos científicos e capítulos de livros, destacamos sua trilogia sobre a ideia de revelação no contexto da pós-modernidade: Deus liberans (MENDOZA, 1996); El Dios escondido (MENDOZA, 2010); e Deus ineffabilis (MENDOZA, 2015a).
} 
fragmentado e perdido, o retorno do religioso dá testemunho da emergência de uma outra ordem de existência que se apropria da experiência de fé como uma vivência de cara para o fundo sem fundo do real. Isto permite pensar nesse fenômeno como oportunidade inédita para a reabilitação daquela experiência com o Mistério transcendente do real, cultivado por todas as tradições religiosas, que em linguagem monoteísta chamamos de Deus. Não se pode esquecer, por outro lado, que o retorno do religioso se constitui em uma severa crítica às religiões institucionais, chamando-as a renunciarem a sua pretensão de domínio sobre as subjetividades e, com isso, superar a sua pretensão de totalidade.

Nesse sentido aberto pela filosofia da religião pós-moderna, Carlos Mendoza afirma que, cedo ou tarde, todo ser humano terá uma experiência de religação com Aquela realidade que o precede e o ultrapassa. Toda subjetividade chegará a tocar no reverso dos processos de subjetivação, onde surge a pergunta por um horizonte de vida para toda a subjetividade em sua relação intersubjetiva, graças ao terreno fértil da linguagem dos símbolos (MENDOZA, 2003, p. 152).

Uma especificidade da experiência religiosa na pós-modernidade niilista é a defesa da "religião sem religião", sob o logos da razão digital que permite uma diversidade de aproximações ao real (MENDOZA, 2010, p. 62). Ora, é preciso esclarecer que a defesa da "religião sem religião" não tem a ver com certo imanentismo, tampouco como negação do fundo amoroso do real. Antes, ela caracteriza-se pelo rechaço aos excessos de significação e sentido por parte das mediações institucionais e, concomitantemente, defende a reabilitação da experiência niilista, apofática e inefável do mistério último do real.

Sob o impacto desse novo movimento cultural, o teólogo mexicano ressalta ao menos dois tipos de niilismos. O primeiro sublinha a conexão entre cristianismo e ateísmo moderno, representado, sobretudo, pelo filósofo italiano Gianni Vattimo. O segundo, um niilismo pós-moderno que se caracteriza pelo diálogo com a experiência religiosa mística, desenvolvido pelo filósofo francês Jean-Luc Nancy 
com seu conceito de "declosión" 2. Esta corrente niilista "rechaça a possibilidade de pensar a Deus como objeto ontológico e propõe postular a realidade divina em sua condição transcendente, metafísica enquanto superessencial e relação mistérica enquanto Infinito” (MENDOZA, 2009, p. 10) 3. Com isso, o niilismo místico abre possibilidade à superação da metafísica da substância e, ao mesmo tempo, à reabilitação daquela metafísica do ser superabundante, “desconhecida por Heidegger" ao formular sua crítica à ontoteologia (MENDOZA, 2016, p. 344). Um niilismo que busca recuperar a experiência de Deus sem identificá-lo como ente ou mesmo com o ser, mas como a fonte do ser.

Sob as novas condições culturais da crise da modernidade e as contribuições do niilismo místico, Carlos Mendoza vê a possibilidade inédita para a devida distinção entre duas ordens do real: a crença e a fé. Segundo ele, a crença é da ordem da religião, do sacrifício, do Deus Todo-poderoso, da metafísica da substância. A fé (fides), por sua vez, é do regime da experiência originária, da kénosis (theosis), do Deus Todo-amoroso, da perpétua doação. Partindo desta distinção - pela via fenomenológica e desconstrucionista - o teólogo mexicano procura reabilitar o talante místico da experiência religiosa. E, com isso, chegar a seu significado originário, que designa uma existência enquanto experiência de religação com o Infinito, na qual aparece a subjetividade capacitada para o divino (homo capax Dei) (MENDOZA, 2007c, p. 16).

Retomam-se, assim, as reivindicações e contribuições do niilismo místico à experiência religiosa possível sob os escombros da modernidade e da cristandade, levando em conta tanto a defesa da "religião sem religião" - com o rechaço da mediação institucional - como o ultrapassamento do cristianismo como totalidade.

\footnotetext{
${ }^{2} \mathrm{O}$ teólogo mexicano esclarece que a Declosión é o processo de desconstrução do cristianismo como origem do Ocidente enquanto narrativa niilista da kénosis que funda o Ocidente. Um abaixamento divino que acontece desde a criação do universo e se consuma na encarnação do Logos divino. De forma que somente num a-teísmo será possível pensar este estágio atual da razão ocidental, visto que o despojo divino implica a renúncia da razão ao poder de toda representação, rito e símbolo que tenha por pretensão esgotar a "origem sem origem" que é Deus em linguagem monoteísta. A declosión, pois, é um neologismo cunhado por Jean-Luc Nancy para postular teoricamente o processo de desconstrução do cristianismo como origem do Ocidente enquanto narrativa niilista do abaixamento divino, isto é, a kénosis que funda o Ocidente (MENDOZA, 2015a, p. 469).

3 "rechaza la posibilidad de pensar a Dios como objeto ontológico y propone postular la realidad divina en su condición trascendente, metafísica en tanto sobre-esencial y revelación mistérica en tanto Infinito". As traduções, para a Língua Portuguesa, das citações diretas do pensamento de Carlos Mendoza, são de nossa responsabilidade.
} 
Acolhem-se criteriosamente as críticas do niilismo pós-moderno, para manter-se vigilante ante os excessos das mediações históricas, do pensamento da totalidade e dos totalitarismos, tanto do pensamento como da ação.

Enfim, pensar a teologia seguindo pela via fenomenológica tem como transfundo a discussão sobre a necessidade de abandono da metafísica. Esta superação tem um contexto preciso: a configuração moderna da subjetividade transcendental ou a objetividade metodológica. Portanto, esta questão da ruptura da metafísica clássica está intrinsecamente relacionada à questão da pertinência e da ressignificação do cristianismo em tempos pós-modernos. De fato, o impacto do pensamento pós-metafísico sobre o cristianismo significa igualmente a desconstrução do sujeito emancipado, cuja autonomia o fazia depender exclusivamente da razão secular para sua realização.

Porém, Carlos Mendoza insiste que o colapso do sujeito moderno colocou em evidência as aporias da razão técnico-científica. Nesta esteira, há tempos alguns pensadores vislumbrando o fracasso do sujeito moderno, colocaram em pauta a questão da pertinência do monoteísmo. Foi precisamente com M. Heidegger e depois com J. Derrida e L-C. Nancy que a questão do monoteísmo passou por uma “virada desconstrucionista” (MENDOZA, 2010, p. 65) 4. Nessa perspectiva, enfatiza o teólogo mexicano, a desconstrução pós-moderna segue na mesma esteira da crítica à metafísica clássica, que identifica Deus e o ser como primeiro Ente. Nessa identificação reside a origem da violência extrema característica do sagrado, como característica do pensamento de totalidade, que cedo ou tarde conduz ao totalitarismo.

$\mathrm{Na}$ esteira dos pós-modernos desconstrucionistas5, sobretudo com Nancy, urge assumir a desconstrução, que implica num processo de inversão típico da

\footnotetext{
${ }^{4}$ Para o teólogo mexicano, Cohen e Franz Rosenzweig foram os pioneiros a pensar a pertinência do monoteísmo no limiar da crise do sujeito moderno, a partir da especificidade judaica, isto é, na lógica de Jerusalém distinta da de Atenas. Apesar de esta reflexão não abarcar a questão da metafísica do Uno, Carlos Mendoza considera que se trata de um pensamento "avant la lettre" que a pósmodernidade posteriormente desenvolveu (MENDOZA, 2010a, p. 65-66).

${ }^{5}$ Para Carlos Mendoza a pós-modernidade desconstrucionista ou pós-modernidade niilista nasce com Jacques Derrida. Ver o Capítulo III de "El Dios escondido" (MENDOZA, 2010, p. 165-224).
} 
fenomenologia, que consiste em "desmontar o fundamento" para postular o Mistério Amoroso do Real - não mais como fundamento - como fonte e evento (MENDOZA, 2010, p. 301). Este processo de desconstrução do cristianismo passa pelo "desmascaramento e da desconstrução do cristianismo como metarrelato" e a "renúncia à totalidade e o desmonte do fundamento", que aparecem como condições indispensáveis para um retornar à coisa mesma da fé cristã. Trata-se de um processo de remoção dos obstáculos à experiência com o mistério Amoroso do real, que em linguagem monoteísta chamamos Deus.

\section{Ultrapassamento da religião como sistema de totalidade}

"A religião chegou a seu esgotamento na forma de totalidade" (MENDOZA, 2007c, p. 17). Todo o processo cultural e filosófico da modernidade tardia leva à constatação de que o esgotamento da religião se deve à sua tentativa de totalização do Mistério. Contra essa perspectiva, os instrumentos da razão crítica, práxica e linguística desencadearam uma verdadeira crise nos modelos totalitários da religião, questionando as expressões doutrinais e morais da religião, sob a alegação de que elas reproduziram e perpetuam a tentativa de esgotar o Mistério no conceito. Apesar do reconhecimento de que o cristianismo não é religião, antes é sua superação, há de se reconhecer sua cumplicidade com o pensamento de totalidade que influenciou o destino do Ocidente.

E, ao contrário do que diz os movimentos contramodernos - como a Ortodoxia radical com John Milbank-, a crítica niilista não pretende identificar-se à rejeição da transcendência ou do fundo místico do religioso. Antes, porém, ela rechaça os excessos de significações e de sentido que a religião propõe na ordem do fundamento e da finalidade da história e da criação, que se tornaram impedimentos para acessar o Fundo Transcendente do Real (MENDOZA, 2010, p. 303-305). Com efeito, o acento na univocidade dos metarrelatos e no discurso totalizador próprio das religiões foi posto em xeque nas sociedades liberais, a partir do horizonte da filosofia, da antropologia e dos movimentos de emancipação social. $\mathrm{E}$, assim, recorda Carlos Mendoza, o direito à diferença assume o seu estatuto 
enquanto rejeição da lógica da mesmidade, da identidade fixa, da pureza da raça e da objetividade da verdade, seja proveniente da consciência seja da visão totalitária da sociedade (MENDOZA, 2010, p. 64).

Esta superação da religião enquanto sistema de crenças e de valores se torna amplamente defendido pela racionalidade pós-moderna niilista 6 . E, nos últimos tempos, o retorno do religioso em sua versão visceral ratifica a necessidade do ultrapassamento da religião pelos pós-modernos, pós-nietzschianos. Essa superação da religião como sistema de totalidade designa a recuperação das fontes místicas da experiência religiosa, experiência de desprendimento, noite escura e êxodo interior no deserto da não representação. Não apenas isso, também implica a superação dos sistemas de totalidade, tanto na doutrina como na moral, e das instituições que subordinam o sujeito (MENDOZA, 2010, p. 113).

Desse modo a desconstrução propugna a superação de todo relato que tenha a pretensão de totalidade, quer seja da religião e dos seus substitutos como a ciência e a tecnologia, quer seja da teoria do estado e da moral patriarcal (MENDOZA, 2007b, p. 112). Os relatos de totalidade têm a pretensão de interpretar a origem e o fim da vida humana. Eles encontram no mito, na religião e na ciência as fases estratégicas deste desenvolvimento de afã de compreensão e de controlo do real (MENDOZA, 2007a, p. 43).

Disso decorre que "Deus é inútil" do ponto de vista das sociedades pósmodernas e de conhecimento, no sentido das representações de "Deus" pela religião, seja como sistema de doutrina e de moral, seja como fundamento ou sentido. Desse processo cultural, emerge a necessidade de desconstrução do monoteísmo, que implica ultrapassar o monoteísmo enquanto sistema de totalidade e, consequente, a constatação do ateísmo como fruto do próprio monoteísmo.

\footnotetext{
${ }^{6}$ Mariano Corbí (ou Marià Corbí) é uma grande referência nesse sentid;, consulte-se sua obra: "Religión sin religión” (1996).
} 


\subsection{Ateísmo como fruto do monoteísmo}

Nesse horizonte, tendo como escopo reabilitar a realidade histórica como o "fundo sem fundo" da fé cristã enquanto relato da liberdade, inserida no processo de evolução da razão, a secularização é compreendida como movimento kenótico do Ocidente. Dá-se o reconhecimento, sobretudo com Gianni Vattimo, da conexão entre o cristianismo e o ateísmo moderno para recuperar tanto a autonomia das realidades terrestres como o fundo sem fundo da fé cristã como legado irrenunciável da liberdade (MENDOZA, 2009, p. 10). Por esta razão, o pensamento niilista pós-moderno - de Jaques Derrida, Gianni Vattimo e de Jean-Luc Nancy propõe a desconstrução tanto do monoteísmo como do cristianismo em seu vínculo indissociável com a história do Ocidente.

Ao percorrer a história do Ocidente, partindo da gênesis de sua formação até os dias de hoje, Carlos Mendoza insiste sobre a tendência de hegemonização da cultura e seu caráter totalizante. Entretanto, em meio a esse pensamento de totalidade, notam-se também germes de sua própria desconstrução, que se evidenciam através dos movimentos culturais de resistência e de insistência na afirmação das diferenças étnicas, sexuais, religiosas, políticas e econômicas (MENDOZA, 2007c, p. 18). É a irrupção, com efeito, dos sujeitos "desencantados, porém imaginativos" (MENDOZA, 2010, p. 169). Desencantados dos metarrelatos, mas que assume a sua exclusão como lugar político capaz de engendrar uma mudança de mundo. Eis, pois os traços constitutivos do "sujeito vulnerável”.

A maior evidência de possível abandono da totalidade se traduz pela formulação do desencanto da pós-modernidade, isso se deve à atitude de ceticismo que a caracteriza frente aos sonhos da racionalidade empírico e formal que atravessa a filosofia e a ciência da modernidade tardia. Nesse sentido, a pósmodernidade é conhecida como "cultura do desencanto" e do fragmento.

\footnotetext{
${ }^{7}$ O sujeito vulnerável é a principal expressão filosófica da racionalidade pós-moderna, que permite a Carlos Mendoza tematizar a subjetividade vulnerável pós-moderna como lugar teológico e como interlocutora de Deus em tempos de fragmentos. Para uma breve aproximação ver: (CALDEIRA, 2017, p. 810-838).
} 
Esta "cultura do desencanto", portanto, se erige com a pretensão de decretar o colapso do modelo de sociedade totalitária que se impôs no Ocidente com anuência da religião. Com isso, nota-se que desde Hegel, Nietzsche e Heidegger se vem anunciando o fracasso de uma determinada versão do cristianismo, intrínseco ao monoteísmo calcado na tríplice fonte abraâmica, helênica e romana. Percebe-se, portanto, segundo o frei dominicano, que essa desconstrução engendrou um processo irreversível de desmantelamento da estrutura de significado desse modelo de crença (MENDOZA, 2007a, p. 43).

Nessa esteira, diversos pensadores como Michel de Certeau, Marià Corbí e Jean-Luc Nancy têm-se ocupado em refletir sobre o desmantelamento do modelo cultural gestado pelo cristianismo como totalidade. Paradoxalmente, seguindo esse pensamento, o teólogo mexicano recorda que esse modelo foi calcado no reconhecimento progressivo da autonomia da criação de modo a se tornar portador de seu próprio ultrapassamento. De certa forma, os vestígios de certo ateísmo do cristianismo o habilita ao seu próprio ultrapassamento.

O ateísmo como fruto do monoteísmo implica a superação permanente das representações do acontecer originario para voltar a este mesmo. Tal postura ateia própria da fenomenología afirma, de maneira radical, a autonomía do mundo e a emancipação do ser humano de qualquer tutela externa, chama-se religião, estado ou mercado [...]. Não se trata de uma negação da divindade enquanto mistério do real, senão de suas representações com pretensões de absoluto, tanto no ámbito da verdade como do sentido e da moral. (MENDOZA, 2007c, p. 18) ${ }^{8}$.

Isso permite afirmar também que, do ponto de vista antropológico, a subjetividade proveniente da (pós) modernidade é o resultado da desconstrução intrínseca do próprio cristianismo em desconstrução. Entretanto, recorda Carlos Mendoza, a renúncia à totalidade precede ao ultrapassamento, visto que essa renúncia supõe uma revisão das pretensões de verdade absoluta. E mais, implica a renúnia à vontade de onipotência nos códigos morais, bem como, de superação das

\footnotetext{
8 “El ateísmo como fruto del monoteísmo implica la superación permanente de las representaciones del acontecer originario para volver a éste mismo. Tal postura atea propia de la fenomenología afirma, de manera radical, la autonomía del mundo y la emancipación del ser humano de cualquier tutela externa, llamase religión, estado o mercado [...]. No se trata de una negación de la divinidad en cuanto misterio de lo real, sino de sus representaciones con pretensiones de absoluto, tanto en el ámbito de la verdad como del sentido y de la moral".
} 
interpretações das mediações unívocas do divino, que afeta todo metarrelato (MENDOZA, 2007a, p. 47).

Em suma, de maneira positiva, o ultrapassamento da religião, especialmente do cristianismo, no contexto da pós-modernidade, implica um duplo movimento. Supõe, por um lado, a recuperação das fontes místicas da experiência religiosa e, por outro, a ruptura de todo sistema de totalidade, abrindo espaço para uma nova experiência religiosa, marcada pelo desapego e pelo êxodo de si mesmo no deserto da não-representabilidade divina (MENDOZA, 2007b, p. 113). Por outro lado, enquanto permanece identificado a um relato de totalidade, o cristianismo não é poupado das críticas desconstrucionistas. Com o desmascaramento do sonho de onipotência infantil e com a consequente queda dos sistemas de totalidade, o cristianismo teve de afrontar-se com as suas próprias idolatrias (MENDOZA, 2007a, p. 48). O esgotamento cultural de um modelo de cristianismo fundamento da civilização ocidental moderna - foi vislumbrado por Hegel, vaticinado por Nietzsche, enfim, alertado pelos mestres da suspeita. Junto com este desmoronamento, evidenciou-se também a emergência da consciência niilista, que interpelou o cristianismo para dar um passo além dos próprios limites confessionais.

Isso conduz o cristianismo a reassumir sua vocação kenótica, isto é, o perpétuo ultrapassamento de si mesmo como sistema religioso e o desmantelamento do sagrado violento. Mas, pensar esse horizonte kenótico da experiência de fé, faz reaparecer o problema da crise metafísica do Ocidente, já que ele fala da experiência histórica da transcendência inscrita na imanência. Enfim, uma experiência aquém e além da metafísica clássica, na qual Deus e o sujeito já não podem mais ser concebidos como onipotentes.

\section{Desmontagem e renúncia do fundamento}

A questão do fundamento marca profundamente a história do Ocidente moderno. Carlos Mendoza sinaliza que a indagação sobre essa questão se configura 
em torno de dois níveis fundamentais. O primeiro aparece na forma de metafísica da causalidade e da finalidade objetiva como verdade última. O segundo, deriva das consequências do primeiro, isto é, da reapropriação das ideologias totalitárias do fideísmo e do racionalismo, cuja personificação foi o progresso. De modo que o fundamento se tornou um projeto colonizador, no qual a ontoteologia e o progresso constitui-se no verso e anverso de um único relato narcisista ocidental, ora como idolatria da substância, ora como idolatria do mercado (MENDOZA, 2010, p. 306).

Foi esse fundamento, em sua dupla faceta, que nos conduziu ao colapso no qual estamos submergidos. Duas versões de totalitarismo sobre uma mesma fonte: a vontade de onipotência. Razões pelas quais a pós-modernidade niilista irá propor a desconstrução do fundamento como condição de possibilidade para chegar ao fundo mistérico do real. Nesse sentido, a desconstrução do fundamento implica a necessária libertação do domínio da onipotência infantil, que marcou tanto a razão ocidental como a fé da cristandade, em suas versões sacrificiais e violentas, como imposição de uma ordem cultural ou religiosa, que esteve no esteio do projeto expansionista colonizador. Da constatação do fracasso terrível desse projeto de civilização, Carlos Mendoza compreende que chegamos no "momento oportuno que nos permitirá chegar ao fundo místico do real, sempre mais exigente que nossos próprios relatos infantis de onipotência” (MENDOZA, 2010, p. 307) 9.

Renunciar e desmontar o fundamento se sobressai como passo indispensável nestes tempos de fragmentos. Sem isso, o acesso ao manancial divino permanece bloqueado pelas estruturas de poder, pelo desejo de obsessão e pela vontade de poder que, cedo ou tarde, desemboca em totalitarismos.

Em suma, importa ressaltar que, se por um lado a pós-modernidade niilista erige-se como crítica à metafísica nos moldes supramencionados, por outro, ela abre espaço para a fenomenologia ontológica. A pós-modernidade niilista não pretende pôr em questão a metafísica como tal, mas redirecioná-la para que a

\footnotetext{
9 “momento oportuno que nos permitirá llegar al fondo místico de lo real, siempre más exigente que nuestros propios relatos infantiles de omnipotencia".
} 
racionalidade pós-moderna possa pensar a experiência religiosa como “fenomenologia metafísica” (DUQUE, 2010, p. 57) ${ }^{10}$. Nessa esteira, Carlos Mendoza insiste na necessidade de abandonar a metafísica da substância em vista de reabilitar a metafísica do ser Superessencial e Superabundante.

\subsection{Além da metafísica como ontoteologia}

$\mathrm{O}$ confronto com a crítica à metafísica na sua vertente religiosa, isto é, à crítica a ontoteologia tão difundida pela racionalidade secular moderna, aparece sempre associada ao combate do pensamento religioso medieval. De modo fortuito, a crítica à metafísica tomasiana parte da correspondência entre o Ser e o Ente supremo; entretanto, o frei dominicano ressalta que não há em Tomás de Aquino uma identificação do Ser com o Ente, pois nele o estatuto epistemológico da questão de Deus situa sua realidade além de toda apreensão conceitual e de todo juízo próprios do intelecto (MENDOZA, 2010, p. 51).

Desse modo a ontoteologia não encontra legitimação em Tomás de Aquino. Antes, ela é fruto do pensamento religioso moderno em continuidade com a Escolástica, marcadas pela tendência de entificar Deus com a pretensão de aceder conceitualmente à transcendência do Deus inefável. Atitude semelhante percebe-se no sentido de coisificação da realidade pela consciência no mundo das ciências modernas. É essa contraposição à metafísica clássica que fez história no pensamento ocidental da totalidade, de modo que a racionalidade pósmodernidade niilista reage ao pensamento metafísico e propugna a renúncia do fundamento; seja em sua versão religiosa ou secular, naquilo em que ela leva a comprometer a invisibilidade do mistério que habita o real.

Ao reabilitar, pois, a perspectiva tomasiana do conhecimento apofático de Deus contra a versão escolástica tardia, Carlos Mendoza visa reabilitar a metafísica

\footnotetext{
${ }^{10}$ Segundo a análise de João Duque, a proposta teológica da "pós-modernidade» não deixa de ser «metafísica», mas trata-se aqui de uma metafísica do amor, da gratuidade, do dom, isto é, da diferença teológica. A diferença ontológica dá-se no ser e no ente como seu fundamento, mas não é a diferença que dá o ser; esta só pode ser a diferença teológica: entre Deus e o ser (comum) dos entes, e entre Deus e a própria diferença ontológica. É, portanto, uma diferença que se dá no ser de Deus, encontrando na doxologia a sua linguagem adequada (DUQUE, 2003, p. 95-96).
} 
da "irrepresentabilidade do Ser", de modo a colocar em questão a pretensão da ontoteologia. A isso, soma-se a nova percepção da subjetividade e da religião do pensamento contemporâneo pós-metafísico de Heidegger, que tende a reforçar a oposição à ontoteologia.

Em suma, o frei dominicano, a partir de sua primeira obra, Deus liberans, insiste que a crise da ontoteologia é devedora de uma confusão originada por uma “decadente escolástica” inspirada em Francisco Suarez (MENDOZA, 1996, p. 439440). Diante disso, destaca três aspectos da influência de Suarez sobre o tomismo da escolástica tardia: a) O problema da ontologização da metafísica do Ipse Esse Subsistens; b) A subordinação da analogia de proporcionalidade à analogia de atribuição; c) A subordinação profunda da liberdade humana ao desígnio divino (MENDOZA, 2010, p. 105-116).

Foi provavelmente esta escola que fixou a metafísica como ontoteologia e aprofundou a confusão da analogia de atribuição intrínseca. Portanto, esta corrente de interpretação barroca da escolástica tomista parece que não foi fidedigna ao pensamento de Tomás de Aquino. Por isso, esta vertente da metafísica como ontoteologia acabou se tornando objeto de crítica da modernidade Ilustrada, primeiro pelo idealismo alemão e depois pelo existencialismo.

\subsection{Aquém da metafísica da substância}

Urge recordar que no contexto da crítica à ontoteologia, desconhecia-se o sentido metafísico do "ser superesensial” de Dionísio Areopagita, como a visão originária do conhecimento que nutriu o pensamento de Tomás (MENDOZA, 1996, p. 146). De todo modo, Carlos Mendoza acredita que, embora a modernidade tenha se equivocado no objeto da crítica à ontoteologia, sua postura foi fundamental para colocar em xeque a "objetividade" das representações do divino e de suas pretensões de absoluto, praticadas tanto no seio do catolicismo quanto no protestantismo. Nesse horizonte, o pensamento pós-metafísico postula uma “ontologia da diferença”, por meio da qual seja possível recuperar a significação de 
uma razão em função de uma "metafísica negativa”. Esta deve ser capaz de abrir-se ao "fundo inominável do real", isto é, a essa realidade inefável evocada de Agostinho ao Mestre Eckhart (MENDOZA, 2015a, p. 42).

Dando um salto histórico, mas percebendo o fio condutor que permite enlaçar o pensamento tomásico e o pensamento pós-moderno, o frei dominicano tende a ressaltar o deslocamento do problema ontoteológico para uma "ontologia da diferença”. É, pois, o caráter apofático da realidade divina que a pósmodernidade niilista se propõe a reabilitar, a partir de sua proposta desconstrucionista. Há, porém, de ressaltar que a experiência niilista sempre existiu na história da humanidade e das religiões, mas ela acabou ocultada pelos relatos de totalidade do Ocidente, seja pela cristandade, seja pela modernidade técnico-científica. Graças à desconstrução, essa experiência do niilismo emerge dos escombros da cristandade e da modernidade como rio fecundo.

Sim, o rio subterrâneo do niilismo apofático percorreu as prados da cristandade, se deslizou depois pelos passadiços da civitas do Ocidente, e agora aparece de novo à superficie da urbe, como fuga de água em meio dos escrombos das torres caídas, através do niilismo pós-moderno. (MENDOZA, 2015a, p. 48) ${ }^{11}$.

Disso decorre que, no contexto da pós-modernidade, é impossível prescindir da crítica à ontoteologia iniciada em Heidegger e radicalizada pelo niilismo pósmoderno. Porque é por meio da desconstrução que se pode ter acesso ao manancial divino, do qual também o cristianismo é portador. Seguindo por esse caminho, juntamente com Nancy chega-se à constatação que o niilismo se identifica a um estágio da evolução da razão ocidental e, consequentemente, à possibilidade de cumprimento da vocação cristã de outro modo de ser que aquele travestido da espiritualidade moderna da autonomia e do iluminismo. No contexto do niilismo, o ser já não pode ser mais objetivado enquanto substância, porque se apresenta como permanente devir, aquém do fundamento, da representação e da finalidade. Essa nova concepção de ser, portanto, exerce forte impacto sobre a teologia.

\footnotetext{
${ }^{11}$ “Sí, el río subterráneo del nihilismo apofático ha recorrido las praderas de la cristiandad, se ha deslizado luego por los pasadizos de la civitas de Occidente, y ahora se asoma de nuevo a la superficie de la urbe, como fuga de agua en medio de los escombros de las torres caídas, a través del nihilismo pósmoderno".
} 
Nesta renuncia ao fundamento, ao sentido e à finalidade radica o niilismo que o sujeito moderno tardío tomará como sinal de consciencia de sua identidade e como seu desafio temporal. O colapso do sujeito implica, em consequência, o desmantelamento da teología como da cosmología como o privativo 'a' que denota ese acontecer originario no qual não há fundo senão devir. (MENDOZA, 2007b, p. 109) ${ }^{12}$.

Desse modo, o niilismo de Nancy que segue de perto Heidegger e Nietzsche, propugna a desconstrução do cristianismo a fim de devolvê-lo à sua novidade antimetafísica e antirreligiosa. Isso ocorre graças à reabilitação do caráter apofático intrínseco do cristianismo, que o torna paradoxalmente uma religião sem religião ou uma experiência ateia do Deus de Jesus Cristo. De fato, a fé judaico-cristã em um Deus criador dá testemunho da criação em categorias niilistas, isto é, da autonomia da criação. Não há, portanto, necessidade de apelar para um fundamento metafísico do real, visto que a "fé de Israel em um Deus criador foi integrada pelo cristianismo em sua leitura da redenção instaurada por Jesus de Nazaré como manando da mesma fonte, a saber: a criação como ser-em-devir, lançada a seu próprio nada, em autonomia em relação a todo fundamento, sentido ou valor" (MENDOZA, 2007b, p. 109-110)13. Seguindo de perto a Nancy, Carlos Mendoza considera esse ateísmo implícito do cristianismo como o grande legado para o Ocidente cristão no contexto da pós-modernidade.

Nancy desenvolve a ideia de uma necessária conclusão ateia na afirmação do Deus criador que de maneira permanente "deixa ser" a sua criação no devir da temporalidade. O cristianismo, por sua parte, é portador deste ateísmo mas em chave cristológica quando afirma, por exemplo, a presença-ausência do crucificado-ressuscitado, ou quando afirma a presença do corpo de Cristo no manancial de sua ausência. Desta perspectiva, o cristianismo leva em si seu próprio ultrapassamento, de modo que sua contribuição à cultura ocidental radica na consciencia do nada, mesmo que se vivencia como renuncia a todo fundamento para viver no reino da liberdade e da imaginação, da finitude e da contigência, da fragilidade e da morte. Tal acontecer originario foi simbolizado pelo cristianismo nascente com a expressão metáforica do evangelho de João

\footnotetext{
${ }^{12}$ En esta renuncia al fundamento, al sentido y a la finalidad radica el nihilismo que el sujeto moderno tardío tomará como señal de conciencia de su identidad y como su desafío temporal. El colapso del sujeto conlleva, en consecuencia, el desmantelamiento de la teología como de la cosmología con el privativo 'a' que denota ese acontecer originario en el que no hay fondo sino devenir.

13 "la fe de Israel en un Dios creador fue integrada por el cristianismo en su lectura de la redención instaurada por Jesús de Nazaret como manando de la misma fuente, a saber: la creación como ser-en-devenir, abocada a su propia nada, en autonomia respecto de todo fundamento, sentido o valor".
} 
com a qual o Ressuscitado se dirige a Maria de Magdala: Noli me tangere... "não me toques, ainda não subi ao Pai" (Jo 20.17). (MENDOZA, 2007b, p. 110) ${ }^{14}$.

Esse movimento de renúncia ao fundamento resulta em uma existência humana e religiosa marcada pelo colapso dos sonhos de "onipotência infantil". Configura-se, portanto, como "testemunho da alteridade, intérprete desolado de sua própria inconsistência, abertura de indigência que faz a existência um pouco mais autêtica” (MENDOZA, 2007b, p. 110). Nisso, radica a contribuição do cristianismo à cultura ocidental enquanto consciência niilista vivenciada como renúncia a todo fundamento e abertura ao acontecer originário. Em outras palavras, abre-se a possibilidade da reconstrução fenomenológica da subjetividade que não se deixa seduzir pelo caráter transcendental do método, graças à desconstrução da pretensão de sentido no ego. Enfim, a desconstrução não afeta somente o problema do fundamento, mas o próprio sujeito que apelava para sua constituição (MENDOZA, 2010, p. 309).

Será então sob o marco referencial desta inversão fenomenológica do ego e da desconstrução da subjetividade que a experiência de fé e a teologia encontram novo terreno para fecundar. E isso em um duplo aspecto segundo a gramática do dinamismo teologal: a) fides enquanto potência de experiência emancipadora do desejo de onipotência; b) fides enquanto conhecimento do outro a partir de Deus, segundo a "inteligência da vítima" 15. Há de se atentar que essa última expressão advém da recepção criativa da "teoria do desejo mimético" de René Girard pela teologia da vulnerabilidade de James Alison (1999). A partir desses elementos, a reflexão entabulada por Carlos Mendoza a respeito da pós-modernidade conduz à ressignificação da fides cristã em torno do paradoxo da subjetividade como

\footnotetext{
14 “Nancy desarrolla la idea de una necesaria conclusión atea en la afirmación del Dios creador que de manera permanente 'deja ser' a su creación en el devenir de la temporalidad. El cristianismo, por su parte, es portador de este ateísmo, pero en clave cristológica cuando afirma, por ejemplo, la presencia-ausencia del crucificado-resucitado, o cuando afirma la presencia del cuerpo de Cristo en el hontanar de su ausencia. Desde esta perspectiva, el cristianismo lleva en sí su proprio rebasamiento, de modo que su aportación a la cultura occidental radica en la conciencia de la nada, misma que se vivencia como renuncia a todo fundamento para vivir en el reino de la libertad y la imaginación, de la finitud y la contigencia, de la fragilidad y de la muerte. Tal acontecer originario fue simbolizado por el cristianismo naciente con la metáfora expresión del evangelio de Juan con la que el Resucitado se dirige a Maria de Magdala: Noli me tangere...'no me toques, todavía no he subido al Padre' (Jo 20.17)".

${ }^{15} \mathrm{O}$ conceito "inteligência da vítima" (intelligence of the victima) foi cunhado por James Alison, em sua criativa recepção da teoria do desejo mimético de René Girard, para descrever a dinâmica interna que inspirou toda a vida de Jesus. A inteligência da vítima designa a própria potência da Ruah divina operando na subjetividade doadora, capacitando-a a compreender o mecanismo mimético que rege as relações intersubjetivas e subvertê-la pela dinâmica do desejo mimético desconstruído da rivalidade (MENDOZA, 2010, p. 273).
} 
potência vulnerável e antirreligiosa do crente. A fim de matizar a compreensão de fides cristã, importa avançar na descrição do modo como o teólogo mexicano a insere nesse processo da desconstrução pós-moderna. Trata-se da maneira como Carlos Mendoza reflete sobre a desconstrução do cristianismo influenciado pela categoria de “declosión”, cunhada pelo filósofo Jean-Luc Nancy. A “declosión” é um neologismo para falar de redução fenomenológica do cristianismo até chegar a sua essência. "Declosión”, pois, está relacionada à ideia de desenclausuramento, reabertura daquilo que foi fechado (NANCY, 2008, 15). Isso possibilitará ao teólogo mexicano delinear os traços constitutivos da essência do cristianismo.

\section{Cristianismo declosionado}

Antes, porém, de debruçar-se propriamente sobre os novos conteúdos do cristianismo pós-moderno, Carlos Mendoza preocupa-se em inseri-lo na esteira da desconstrução. E isso em função da sua identificação com uma forma de relato unívoco de totalidade e de seu discurso absoluto antropocêntrico e do desejo de onipotência que o atravessou por séculos de história. Urge mostrar que, se há quase simbiose entre o Ocidente e o cristianismo, avançar na compreensão do colapso do sujeito moderno e da consequente consciência niilista pós-moderna leva evidentemente a associar tal desmantelamento ao cristianismo. Seja porque se sente atingido pela desconstrução, seja porque ele desconstruído pode conduzir a desconstrução do imaginário cultural do Ocidente.

Desconstruir significa, neste contexto preciso, o desbloqueio do manancial divino antes que fique coberto pelas mediações simbólicas. Isto implica certamente em um retorno às fontes, mas não no sentido do reenconto com o feito histórico fundador em sua objetividade empírica, nema inda menos com seu enigma mitológico, senão no sentido de um retorno fenomenológico à coisa mesma. (MENDOZA, 2010, p. 304) ${ }^{16}$.

Com isso não se pode confundir o movimento de "voltar à coisa mesma" da fé com a pretensão de voltar à identidade confessional ou, como defendem os

\footnotetext{
16 "Desconstruir significa, en este contexto preciso, el desbloqueo del manantial divino antes de que quede cubierto por las mediaciones simbólicas. Esto implica ciertamente un retorno a las fuentes, pero no en el sentido del reencuentro con el hecho histórico fundador en su objetividad empírica, ni aún menos con su enigma mitológico, sino en el sentido de un retorno fenomenológico a la cosa misma".
} 
movimentos contramodernos, a uma preocupação de "voltar ao fundamento"17. Antes, se trata de um voltar ao cristianismo associado à "fonte originaria de seu nascimento que é o real mimético que se desvela como clamor, convite, carícia, ausência”, seguindo a interpretação de Nancy (MENDOZA, 2007a, p. 48) 18. Tratase de voltar à experiência fundacional pascal de Cristo, que do ponto de vista antropológico e fenomenológico assume o rosto da superação do ódio e do nascimento de uma identidade relacional marcada pela gratuidade (MENDOZA, 2010, p. 304).

Exatamente nisto radica a proposta da desconstrução do cristianismo, uma vez que ao abandonar esses relatos de totalidades calcados na visão de sujeito absoluto e de um Deus onipotente, esse movimento provoca o colapso do sujeito moderno a ponto de viabilizar o acesso ao fundo "místico do real". Visto que tal colapso é a condição mesma da desconstrução, Carlos Mendoza associa essa ideia àquela da antropologia de Levinas, a respeito da sua reflexão sobre a "fissão do núcleo do sujeito" provocada pelo contato com a alteridade do outrem que é sempre da ordem do enigma (MENDOZA, 2007c, p. 25).

Tendo presentes esses elementos, o teólogo mexicano cogita a possibilidade de o cristianismo poder pensar a correlação humano-divino no advento da subjetividade exposta com sua experiência de kénosis e theosis. E, consequentemente, pensar sua própria pertinência em tempos pós-metafísicos. Nesse sentido, trata-se de perscrutar a desconstrução do cristianismo como algo constitutivo de si mesmo e chegar ao reconhecimento de que o niilismo pósmoderno não é outra coisa que a realização do próprio cristianismo, se concebido a partir da lógica da kénosis-theosis.

O principio kenótico revela a potencia divina como fonte de alteridade e de comunhão na diferença. Com efeito, o logos se fez carne para que a carne se deifique segundo aquela máxima de são Irineu de Lyon que sintetiza o movimiento salvífico: a kénosis se encontra profundamente orientada à theosis ou deificação. Trata-se de um dinamismo de

\footnotetext{
${ }^{17}$ Acerca dos movimentos contramodernos e sua defesa da volta ao fundamento, que em vista de uma razão cordial são interlocutores de Carlos Mendoza, ver o Capítulo II de "El Dios escondido", (MENDOZA, 2010, p. 95-163).

18 "fuente originaria de su nacimiento que es lo real mistérico que se devela como clamor, invitación, caricia, ausencia, anhelo".
} 
transcendência que dá pleno sentido e força final à imanência. A encarnação ou, dito de outro modo, o despojo da condição divina aponta à incluso de toda a criação pelo ato de amor que a conduz à vida divina. Eis aquí um sentido por sua vez transcendente e fenomenológico da polaridade criadora kénosis-theosis que nos localiza no coração da inteligência teologal do real. (MENDOZA, 2010, p. 327) ${ }^{19}$.

Levando em conta esse horizonte, o teólogo mexicano se refere ao seu pensamento como uma "teologia niilista" cunhada em função da temporalidade kairológica e messiânica. Isso porque, graças à centralidade da história kenótica realizada em Jesus de Nazaré, tornou-se passível de cumprimento esse dinamismo salvífico na subjetividade exposta pela presença amorosa da vítima que sabe perdoar $^{20}$. E mais, para além da crítica contramoderna, o nuilismo pós-moderno, em consonância com a desconstrução do cristianismo, possibilita a reabilitação da transcendência no coração da imanência. De fato, com a apropriação da virada hermenêutica kenótica de corte niilista, falar de Deus agora se converte numa maneira de dizer o humano exposto ao mistério. Essa maneira niilista de falar de Deus a partir do ser humano se tornou possível graças ao sentido filosófico da religião articulada à luz de uma ontologia relacional na gratuidade ${ }^{21}$ e sua permanente abertura à transcendência.

O fato de falar de Deus e dizer o ser humano de maneira concomitante representa um modo de estar-no-mundo que vincula ao sujeito a sua aventura de emancipação ao mesmo tempo que o reenvia ao mistério do real sem absolvê-lo da responsabilidade ética pelo outro na história.

\footnotetext{
19 “El principio kenótico revela la potencia divina como fuente de alteridad y de comunión en la diferencia. En efecto, el Logos se ha hecho carne para que la carne se deifique según aquella máxima de san Ireneo de Lyon que sintetiza el movimiento salvífico: la kénosis se encuentra profundamente orientada a la theosis o deificación. Se trata de un dinamismo de trascendencia que da su pleno sentido y su fuerza final a la inmanencia. La encarnación hace actual la deificación por la intermediación de la humanización o, dicho de otro modo, el despojo de la condición divina apunta a la inclusión de toda la creación por el acto de amor que la conduce a la vida divina. He aquí un sentido a la vez trascendente y fenomenológico de la polaridad creadora kénosis-theosis que nos ubica en el corazón de la inteligencia teologal de lo real".

${ }^{20} \mathrm{O}$ conceito "vítima que sabe perdoar o" ou "vítima perdoadora" (The forgiving victim), designa a original intuição do teólogo britânico James Alison em sua "recepção criativa" da teoria mimética de René Girard. Em Carlos Mendoza a aparição do Crucificado-que-vive como vítima que perdoa a seus verdugos, revela a "(im) potência potente", isto é, o desejo mimético desconstruído da rivalidade, como núcleo da subjetividade e, assim, inaugura uma nova ontologia relacional marcada pela gratuidade (CALDEIRA, 2018, p. 307-323).

${ }^{21}$ No pensamento teológico de Carlos Mendoza, a redenção no contexto da pós-modernidade é compreendida a partir do desenvolvimento de uma ontologia relacional na gratuidade, na qual se pode compreender a revelação do mistério humano-divino cujo ápice se deu em Jesus de Nazaré. Essa ontologia relacional marca uma ruptura epistemológica em relação à ontologia da substância, cuja característica principal é a substância e não a relação (KNAUER, 2012, p. 19-41). Nessa ontologia relacional na gratuidade descrevese a constituição da subjetividade vulnerável em sua relação constitutiva com a alteridade e com a transcendência, como modo de existência capaz de pôr fim à violência e, assim, engendrar a construção de um mundo melhor. Isso significa superar a inércia que a teologia clássica nos conduziu, ao apostar no poder extrínseco e mágico para nos salvar. E mais, essa ruptura com uma visão intervencionista de salvação leva à afirmação da redenção como uma transformação que irrompe "desde abajo y desde el reverso" pela subjetividade aberta ao devir incerto da história (MENDOZA, 2015a, p. 88).
} 
Assim, o sujeito exposto deve tomar a seu cargo o conhecimento, a liberdade e a poiesis que emanam de sua condição de ser na imanência, mas constitutivamente aberta à transcendência. (MENDOZA, 2010, p. 55, grifo autor) ${ }^{22}$.

Carlos Mendoza, pois, se apropria da desconstrução da religião levada a termo pelos niilistas pós-modernos, para insistir que o princípio da kénosis do Verbo torna-se a gênese do ultrapassamento da religião como totalidade (MENDOZA, 2007b, p. 110). Ora, com isso recupera-se o fundo metafísico da existência em devir e preserva o "niilismo constitutivo do real". Desse modo, coube ao teológo mexicano explicitar o processo de desconstrução que se instala no ocaso do Ocidente em função de seus traços monoteístas e kenóticos. Ao retomar as afirmações de Nancy, ele recorda que o cristianismo é essencialmente o movimento de sua própria distensão. Graças ao fato de o cristianismo ser uma experiência antropológica ele também viabiliza o lugar da constituição de um sujeito aberto e na distensão de si mesmo.

Essa distensão constitutiva do cristianismo aparece, sobretudo, no seu anúncio apocalíptico, isto é, no "anúncio do fim" como "boa nova". Disso decorre que a fé judaico-cristã em um Deus criador conversa a consciência ateia como um elemento estruturante da religião sem religião. Isso significa que o cristianismo traz em si mesmo a semente de certo ateísmo e sua própria superação. E, consequentemente, "é portador consciente de sua finitude e caducidade como sistema de representa, de valor ou inclusive de religião" (MENDOZA, 2007a, p. $53)^{23 .}$

Nesse processo de matizar e ressaltar o caráter niilista do cristianismo, Carlos Mendoza retoma a antropologia do desejo mimético de René Girard. Este apresenta o cristianismo como superação da religião, porque não é doutrina senão horizonte e porque desmantela os mecanismos da reciprocidade violenta e da dialética como cumprimento da história (MENDOZA, 2009, p. 18). Enfim, diante

\footnotetext{
22 "El hecho de hablar de Dios y decir al hombre de manera concomitante representa un modo de estar-en-el-mundo que vincula al sujeto a su aventura de emancipación al mismo tiempo que lo reenvía al misterio de lo real sin absorverlo de la responsabilidad ética por el otro en la historia. Así, el sujeto expuesto debe tomar a su cargo el conocimiento, la libertad y la poiesis que se desprenden de su condición de ser en la inmanencia, pero abierta constitutivamente a la trascendencia".

23 "es portador consciente de su finitud y caducidad como sistema de representación, de valor o incluso de religión".
} 
disso, reconhecendo que o ateísmo é fruto da própria evolução do cristianismo, o teólogo mexicano assegura: “não precisamos ter medo dele” (MENDOZA, 2015b), porque o cristianismo assume o lugar de uma theosis.

\section{Absenteísmo: nova expressão da transcendência}

Na mesma direção, de um cristianismo pacífico percebe-se que Carlos Mendoza se apropria do pensamento de Nancy para enfatizar o vínculo estreito que há entre o cristianismo e a consciência niilista iconoclasta e apofática da existência além da essência ${ }^{24}$. É, pois, graças ao pensamento de Nancy, que o niilismo será assumido em sua materialidade expressiva como parte do desdobramento da razão ocidental. Segundo o teólogo mexicano, o niilismo colocou em questão a ideia fundacional do monoteísmo judaico aliado à ideia de uma só humanidade, pois essa ideia não dá conta da secularização e da desconstrução intrínsecas ao próprio cristianismo.

A ideia cristã da encarnação do Verbo divino foi necessária para levar a seu clímax a correlação Deus-mundo. E neste proceso kenótico, do qual dá testemunho o cristianismo com seu credo e com sua pregação do amor universal, aparece o esvaziamento do ser como a metáfora principal para falar do 'desfundamento' do Ocidente. Será, portanto, o monoteísmo, em sua atrevida e inovadora versão cristã da encarnação de Deus, o que permitirá ao pensamento ocidental postular a insuficiencia radical de toda representação para dizer, representar, pensar ou conduzir a existencia à ação, em sua nudez. (MENDOZA, 2015a, p. 80-81)25.

No último volume da sua trilogia, Carlos Mendoza explora com mais afinco a perspectiva nancyniana a respeito do desmantelamento do sentido e do fundamento que serviu de justificação da razão secular (MENDOZA, 2015a, p. 8088). É, pois, a “declosión” do fundamento da razão secular que possibilita o “desfundamento" do Ocidente. Há de se deixar claro que, para além da crítica dos movimentos de retorno à metafísica, o niilismo pós-moderno não rechaça a

\footnotetext{
${ }^{24}$ Acerca disso Nancy declara que "el cristianismo es por sí mismo, en sí mismo, una deconstrucción o una autodeconstrucción. Es también por este carácter que representa a la vez la forma más occidentalizada -y/o occidentalizante /.../ del monoteísmo. El cristianismo, en otros términos, indica la manera más activa - y también la más ruinosa para sí misma, la más nihilista en ciertos aspectos - por la que el monoteísmo abriga en sí - o mejor: más íntimamente en sí que sí mismo, más acá o más allá de sí mismo - el principio de un mundo sin Dios" (NANCY, 2008, p. 59-60).

25 "La idea cristiana de la encarnación del Verbo divino fue necesaria para llevar a su clímax la correlación Dios-mundo. Y en este proceso kenótico, del que da testimonio el cristianismo con su credo y con su pregón del amor universal, aparece el vaciamiento del ser como la metáfora principal para hablar del 'desfondamiento' de Occidente. Será, por tanto, el monoteísmo, en su atrevida e innovadora versión cristiana de la encarnación de Dios, el que permitirá al pensamiento occidental postular la insuficiencia radical de toda representación para decir, representar, pensar o llevar la existencia a la acción, en su sola desnudez".
} 
transcendência, mas segue na aposta da morte do sujeito metafísico. Nesse horizonte, em chave fenomenológica, a “declosión” do cristianismo resultará no “absenteísmo" (MENDOZA, 2007c, p. 20). Trata-se de outra forma de transcendência a partir da imanência do ser-em-devir. Uma concepção da realidade divina enquanto “origem sem origem do ser”, isto é, como Dasein. Uma concepção divina análoga ao conceito grego de agénetos, para explicar a fontalidade do amor divino da teologia trinitária dos Capadócios. Longe de afirmar um deus ex machina como motor imóvel, faz-se a experiência com o divino sob o oximoro da presença-ausência ontológica enquanto ser em devir. "Postulação então de um caos originário, meta-físico e, por isso mesmo, sem sentido, preconceitual, da ordem da trans-imanência” (MENDOZA, 2007c, p.21) ${ }^{26}$.

Consequentemente, esse "absenteísmo", isto é, nessa experiência da transcendência desde a imanência, a partir de sua ação iconoclasta, rechaça a visão de um deus intervencionista típica da metafísica da causalidade. E, concomitantemente, afirma a impossibilidade de consolação divina para o sujeito refém das imagens transcendentes de Deus ou da finalidade da criação. O que resta, portanto, após o rechaço da falsa segurança, é a afirmação da subjetividade "colapsada” após a renúncia da segurança do fundamento. A subjetividade "declosionada" enquanto "corpo como ferida aberta", isto é, fica radicalmente aberta e exposta ao mundo, aos outros, ao inefável e à incomensurabilidade da relação entre as subjetividades (MENDOZA, 2015a, p. 85-88).

Ora, o colapso do sujeito inaugura a aparição da subjetividade débil27, que desconstrói suas pulsões de controle e manipulação e, concomitantemente, renuncia à objetivação do real como afirmação da lógica da mesmidade. Entretanto, importa ressaltar neste momento que se segue o impacto da “declosión” da subjetividade sobre a experiência religiosa. Trata-se de pensar que a subjetividade esvaziada de fato pode então descobrir-se em estado de adoração

\footnotetext{
26 "Postulación entonces de un caos originario, meta-físico y, por lo mismo, sin sentido, preconceptual, del orden de la transinmanencia".

${ }_{27}$ Para uma descrição da fenomenologia da subjetividade débil ou vulnerável segundo o pensamento de Carlos Mendoza, ver: (CALDEIRA, 2017, p. 810-838).
} 
(MENDOZA, 2015a, p. 67-68). Nesse estágio de abertura à alteridade, a subjetividade pode pronunciar uma palavra como saudação a outrem. Essa é, portanto, a única “realidade palpável” que resta à subjetividade: sua indigência e exposição à alteridade.

Graças a essa percepção da subjetividade, Carlos Mendoza reivindica o caráter ético desse absenteísmo divino originário, exatamente porque ele pode afirmar a pertinência do cristianismo em contexto pós-metafísico. Dito de maneira positiva, a fim de justificar a atuação de Deus na história humana, o teólogo mexicano afirmará a transcendência na imanência da subjetividade exposta e em doação. Dentre os monoteísmos, afirma ele, o cristianismo foi aquele que apareceu como o ultrapassamento do sistema religioso com sua ideia de "eschatón": o tempo pleno além e aquém da temporalidade mesma (MENDOZA, 2007c, p. 28).

Agora sob a égide da racionalidade pós-moderna, o "eschatón” é compreendido em seu caráter apofático e messiânico como "tempo contraído”, com a reabilitação da escatologia paulina, sobretudo com Giorgio Agamben. Nesse caso, a temporalidade em perspectiva messiânica instaura uma fissura na história como uma ordem nova para a condição humana, que chega por meio dos atos de extrema doação dos justos da história e de maneira radical pelas vítimas perdoadoras. Esses tempos discretos irrompem segundo os gestos fundacionais da gramática bíblica, em que a vida vence a morte através da concreção histórica da extrema doação da subjetividade em sua “(im) potencia potente” ${ }^{28}$, isto é, do desejo mimético desconstruído da rivalidade (MENDOZA, 2010, p. 229).

De fato, a ideia de messias sempre designou a tentativa de falar da ação divina na história da humanidade. Mas, segundo Carlos Mendoza, no judaísmo esta ideia ainda aparece sob a figura de totalidade. O cristianismo, por sua vez, representa a prova contundente da fissura naquilo que há de totalidade no sistema religioso judaico. Em outras palavras, o cristianismo aparece em seu aspecto de

\footnotetext{
28 "Impotência potente" é uma glossa nossa ao "poder do não-poder" que procede da gratuidade amorosa, cujo sentido denota o mimetismo depurado de sua rivalidade. Quando o Messias Jesus aparece como "vítima perdoadora" ele revela que o núcleo da subjetividade unida à temporalidade escatológico é sua "impotência potente".
} 
"sacramentalidade" de modo a implodir o caráter sistêmico e totalitário da religião sacrificial. Surge assim outra ordem de realidade, à qual as discípulas e os discípulos são convidados a pertencer e capacitados a habitá-la sacramentalmente. Nisso consiste o aspecto da sacramentalidade da experiência de fé como fissura da significação, pois a única maneira de descrever a vida eterna passa pela desconstrução do corpo histórico. Nesta perspectiva teológico-fenomenológica aparece com vigor a possibilidade de uma nova "teologia kenótica", com a qual seja possível justificar o encontro humano-divino no seio da racionalidade pósmetafísica.

Tais são os paradoxos que abrem a fissura da significação: não há significado possível de vida eterna senão desconstruindo um corpo histórico. Não há sentido senão no semsentido do morto-vivente. Não há mesianismo senão a partir do rosto de um humano desfigurado... Não há nome de Deus que seja pronunciável senão a partir da orfandade assumida. Niilismo da nascente, originária, indeterminda de qualquer utilidade ou interesse. (MENDOZA, 2007c, p. 32) ${ }^{29}$.

Depois dessa exposição do caráter kenótico do cristianismo por meio da desconstrução, o teólogo mexicano retoma a experiência de Jesus de Nazaré e seu complexo dinamismo constitutivo para justificar uma teologia kenótica em tempos pós-modernos. Este dinamismo constitutivo será o correlato da teologia apofática dos nomes divinos e imagens de Deus possíveis, isto é, o processo de encarnação de Jesus e, concomitante, esvaziamento divino. O que leva a termo o processo kenótico não é apenas a constituição complexa da sua dupla natureza, mas os “ditos e feitos" de Jesus que culminaram em sua aniquilação. Processo kenótico levado a seu paroxismo com o anuncio do Crucificado-Ressuscitado, cujo acesso vem doado pelas narrativas simbólicas enunciadas em "chave de desapego": "Noli me tangere... Subo a meu Pai (Jo 20.17), Vão à Galileia: lá me verão (Mt 28.10; Mc 16.7)”30, que Carlos Mendoza as associa às dimensões polissêmicas do absenteísmo enquanto despertam um novo modo de estar-no-mundo, por meio da fé (MENDOZA, 2007c, p. 32). Evidentemente, uma fé marcada pela lógica do rebaixamento.

\footnotetext{
${ }^{29}$ "Tales son las paradojas que abren la fisura de la significación: no hay significado posible de vida eterna sino desconstruyendo un cuerpo histórico. No hay sentido sino en el sinsentido del muerto-viviente. No hay mesianismo sino desde el rostro de un humano desfigurado...No hay nombre de Dios que sea pronunciable sino desde la orfandad asumida. Nihilismo de la naciente, originaria, indeterminada de cualquier utilidad o interés".

30 “Noli me tangere... Subo a mi Padre (Jn 20.17), Vayan a Galileia: allá me verán (Mt 28.10; Mc 16.7)".
} 


\subsection{Fé niilista sob a gramática do rebaixamento}

Importa avançar e enfatizar a dimensão niilista da fé, sob o signo do rebaixamento cujo sentido só pode apresentar-se em uma dimensão apofática. Ora, nesta tensão semântica da presença-ausência emerge a fé, enquanto uma presença rememorativa. A fé em sua significação niilista aparece como uma reabilitação da vida mística, na qual se experimenta a presença silenciosa do Deus inefável como radical abertura do ser. Uma experiência passível de ser vivenciada somente no tom da contemplação. Partindo, pois, do pathos contemplativo, aproxima-se dos traços constitutivos de uma fé capaz de ser vivenciada pela subjetividade vulnerável em seu anelo por "mudança de mundo". Essa fé no seio da racionalidade pósmoderna emerge como experiência de desprendimento e lançamento ao abismo do ser superabundante divino.

A fé, em seu sentido niilista, é uma cavidade de significado: um conhecimento de Deus sem imagens porque é fruto do desapego da existência que se reconhece, em meio a orfandade dos signos, habitada por uma presença amorosa. Tal experiência silenciosa da presença divina, como radical abertura do ser, adquire cores inusitadas no meio dos escombros da modernidade. É suscetível de ser vislumbrada só no teor da contemplação. Quando cessam as imagens, os conceitos e até as razões e as decisões. Quando não parece existir senão o nada e o vazio, apesar disso, se ama. (MENDOZA, 2015a, p. 415) 31. $^{1}$.

Essa fé niilista, portanto, é coetânea da "potência impotente" da subjetividade declosionada (MENDOZA, 2007b, p. 112), estágio que representa também a passagem de "mundo da crença" para o mundo iconoclasta e apofático, isto é, o mundo da fé sem a idolatria do sujeito. Este mundo outro da fé surge da lógica do desprendimento, da subjetividade "declosionada", "desconstruída”, “colapsada”. Trata-se da subjetividade esvaziada, entregue ao desmantelado da lógica da identidade ao mesmo tempo em que se encontra numa abertura radical à irrupção da lógica da gratuidade sob o signo iconoclasta, lugar do "puro dom" (MENDOZA, 2007c, p. 43). Esta será a aposta da fé niilista, na qual a subjetividade

\footnotetext{
31 “La fe, en su sentido nihilista, es una oquedad de significado: un conocimiento de Dios sin imágenes porque es fruto del desapego de la existencia que se reconoce, medio de la orfandad de los signos, habitada por una presencia amorosa. Tal experiencia silenciosa de la presencia divina, como radical apertura del ser, adquiere colores inusitados en medio de los escombros de la modernidad. Es susceptible de ser vislumbrada solo en el tenor de la contemplación. Cuando cesan las imágenes, los conceptos y hasta las razones y las decisiones. Cuando no parece existir sino la nada y el vacío y, a pesar de ello, se ama".
} 
declosionada fica exposta a seu próprio devir, assumindo o real que lhe é dado, no qual o fundamento não lhe faz falta (MENDOZA, 2007b, p. 112).

Neste sentido constata Carlos Mendoza que, por meio do niilismo pósmoderno, se evidencia o esgotamento de um modelo de cristianismo, mas não da fé que encontra um novo locus nos escombros da modernidade e da cristandade. Assim, a fé segundo a tradição apofática do cristianismo medieval readquire grande vigor no contexto pós-moderno, embora deposta do imaginário religioso teocêntrico (MENDOZA, 2007a, p. 53). Não se relaciona à fuga da realidade, pelo contrário, através dela a subjetividade assume a realidade como dom e único lugar da plena realização humana indo além do horizonte da autonomia moderna e do teocentrismo medieval.

Eis, pois, segundo Carlos Mendoza, a vigência do cristianismo em tempos pós-cristãos, marcado por uma fé apofática que emana do sujeito colapsado capaz de balbuciar o nome de Deus, não como uma realidade objetiva e circunscrita mundanamente (no mundo das crenças, dos ídolos), mas enquanto ícone. Com efeito, uma experiência possível a uma subjetividade vulnerável, capaz de balbuciar nomes divinos enquanto representação contingente da realidade sempre outra (MENDOZA, 2007c, p. 49).

Enfim, a desconstrução do cristianismo, com sua ideia de "redução fenomenológica”, busca voltar a "coisa mesma” da fé cristã com o objetivo de manter-se fiel à sua origem. Ultrapassando a objetivação e a manipulação do real que dela resulta, a desconstrução niilista com sua lógica iconoclasta tem seu grande mérito de pôr em questão a idolatria, visto que o "niilismo tem a virtude de levar ao extremo a lógica iconoclasta: seja para desmascarar a idolatria do conceito no âmbito da inteligência, ou da moral e da religião na ordem da vontade” (MENDOZA, 2010, p. 338) 32.

\footnotetext{
32 "El nihilismo tiene la virtud de llevar al extremo la lógica iconoclasta: sea para desenmascarar la idolatría del concepto en el ámbito de la inteligencia, o de la moral y la religión en el orden de la voluntad".
} 
De fato, em sua teologia fundamental pós-moderna, o teólogo mexicano propugna a significação da fé cristã a partir da fonte fenomenológica e iconoclasta. Entretanto, ele critica a "esterilidade" do niilismo, porque, se por um lado liberta do egocentrismo da razão ilustrada, por outro, submerge o sujeito vulnerável na impossibilidade da compreensão do real, bem como da afirmação de si, do mundo e de Deus mesmo. "Seu apofatismo para a meio caminho entre a derrubada da substância e o nada do Dasein”(MENDOZA, 2010, p. 338) 33.

Carlos Mendoza está convencido, pois, da impossibilidade de renunciar a esse novo horizonte aberto pelo niilismo místico, em seu modo de recolocar de "maneira diferente diante do real", aquém da lógica do mesmo-idêntico, da manipulação do real. Contudo, ele afirma que sua mediação é insuficiente, por isso a necessária intersecção com a mediação antropológica para uma "heurística da esperança”. Assim, "mais que ficarmos paralisados com o olhar diante do abismo, necessitamos descobrir a potência dessa experiência diferente que faz possível o cristianismo como ultrapassamento perpétuo de si como doação e gratuidade e, em última instância, afirmação da vida” (MENDOZA, 2010, p. 338) 34.

Enfim, a partir da mediação fenomenológica e antropológica, Carlos Mendoza empreende um movimento de volta ao "fundo sem fundo do real", a partir das margens da história de exclusão e de violência; ele está convencido da impossibilidade de fazer teologia pós-moderna sem o "imperativo ético e místico" da proximidade das vítimas sistêmicas. Disso resultará nos traços constitutivos do cristianismo pós-moderno, no qual a experiência cristã de Deus acontece a partir da exposição da subjetividade à presença da vítima que sabe perdoar.

\footnotetext{
33 "Su apofatismo se detiene a medio camino entre el derrumbe de la sustancia y la nada del Dasein".

${ }^{34}$ "más que quedar paralisados con la mirada frente al abismo, necesitamos descubrir la potencia de esa experiencia diferente que hace posible el cristianismo como rebasamiento perpetuo de sí como donación y gratuidad y, en último término, afirmación de la vida".
} 


\section{Conclusão}

Todo o percurso fenomenológico trilhado até o presente momento tem como pano de fundo a maneira antissistêmica e pós-moderna de resolver o enigma da violência intersubjetiva. Contudo, sabe-se que as aporias do espaço público não encontram solução nesta história por causa de sua finitude. Razão pela qual cabe à teologia negar o mundo enquanto sentido último do real e afirmar a realidade do Reinado de Deus que advém como promessa cumprida por Deus através de Jesus de Nazaré. Por esta razão, afirma o teólogo mexicano, caberá ao olhar cordial da fé, não apenas constatar o acontecer fenomenologicamente, mas "estimular" seu cumprimento (Mendoza, 2010, p. 339).

Em suma, todo esse processo de desconstrução do cristianismo como totalidade religiosa, do desmantelamento de sua pretensão de absoluto e desativação do desejo de onipotência, assume o papel fundamental no pensamento teológico de Carlos Mendoza. Despois de passar pela crítica desconstrucionista, torna-se possível delinear os traços constitutivos do cristianismo pós-moderno e, assim, por em revelo a sua pertinência e significação em tempos de fragmento. Esse processo lhe possibilitará fazer uma "epoche" dos sistemas de crenças para chegar ao evento originário da fé, que não é da ordem da objetividade empírica, antes é de natureza antropológica e fenomenológica. Trata-se da superação do ódio e da constituição da identidade relacional. Nesse cristianismo pós-moderno, isto é, na experiência cristã de Deus, a subjetividade vulnerável aparece como a principal interlocutora de Deus, que se revelou plenamente na fraqueza do Messias crucificado e por analogia se revela nos atos de extrema gratuidade dos justos da história. 


\section{REFERÊNCIAS}

ALISON, J. El retorno de Abel. Las huellas de la imaginação escatológica. Barcelona: Helder, 1999.

CALDEIRA, C. Teologia e niilismo pós-moderno: a subjetividade vulnerável como locus theologicus no pensamento de Carlos Mendoza Álvarez. Pistis \& Práxis, Curitiba, v. 9, n. 3, p. 810-838, 2017.

CALDEIRA, C. Dá Europa à América Latina. A vulnerabilidade como locus theologicus. Perspectiva Teológica, Belo Horizonte, v. 50, n. 2, p. 307-323, 2018.

CORBÍ, Mariano. Religión sin religión. Madrid: PPC, 1996.

DUQUE, J. M. Experiência religiosa e metafísica: breve leitura de Jean-Luc Marion. In: SUMARES, M.; CATALÃO, H. B.; VALINHO GOMES, P. Religiosidade: o seu carácter irreprimível. Perspectivas contemporâneas. Braga: Faculdade de Filosofia, 2010. p. 57-68.

DUQUE, J. M. Dizer Deus na pós-modernidade. Lisboa: Alcalá, 2003.

MENDOZA ÁLVAREZ, C. El Dios otro. Un acercamiento a lo sagrado en el mundo pósmoderno. México: Universidad Iberoamericana, 2003.

MENDOZA ÁLVAREZ, C. Sobre el rebasamiento del cristianismo como totalidad. In: MENDOZA ÁLVAREZ, C. (Coord.). La universidad de inspiración cristiana en tiempos e poscristiandad. México: Universidad Iberoamericana, 2007a. p. 41-55.

MENDOZA ÁLVAREZ, C. El colapso del sujeto posmoderno: nihilismo y mística. In: C. Mendoza Álvares (Coord.). Subjetividad y experiencia religiosa pós-moderna. México: Universidad Iberoamericana, 2007b. p. 81-113.

MENDOZA ÁlVAREZ, C. Dios es inútil. Por una desconstrucción de las imágenes de Dios. In: HEREDIA, J.; ZUBIRÍA, G. (Coord.). Imágenes de Dios en el mundo contemporâneo. México: UITCAM, 2007c. p. 15-52.

MENDOZA ÁlVAREZ, C. El diálogo fe y razón en contexto de globalización. Piezas en Diálogo, Filosofía y Ciencias Humanas, Jaisco, v. 6, n. 8, p. 7-24, jun. 2009.

MENDOZA ÁLVAREZ, C. Sobre el rebasamiento del cristianismo como totalidad. In: MENDOZA-ÁLVAREZ, C. (Coord.). La universidad de inspiración cristiana en tiempos de poscristiandad. México: Universidad Iberoamericana, 2007a. p. 41-55.

MENDOZA ÁLVAREZ, C. Deus ineffabilis. Una teología posmoderna de la revelación del fin de los tempos. Barcelona: Herder, 2015a.

MENDOZA ÁLVAREZ, C. Heidegger y la teología posmoderna. Diálogo en torno a la situación histórica del tiempo kairológico. Pistis \& Praxis, Curitiba, v. 8, n. 2, p. 337-365, 2016. 
MENDOZA ÁLVAREZ, C. Deus liberans. La revelación cristiana en diálogo con la modernidad. Los elementos fundacionales de la estética teológica. Fribourg: Éditions Universitaires, 1996.

MENDOZA ÁlVAREZ, C. El Dios escondido de la posmodernidad. Deseo, memoria e imaginación escatológica. Ensayo de teología fundamental pós-moderna. Guadalajara: SUJ, 2010.

MENDOZA ÁLVAREZ, C. Seminário internacional de teologia. PUCPR, 2015b.

MENDOZA-ÁLVAREZ C. El colapso del sujeto posmoderno: nihilismo y mística. In: MENDOZA ÁLVAREZ, C. (Coord.). Subjetividad y experiencia religiosa pósmoderna. México: Universidad Iberoamericana, 2007b. p. 81-113.

NANCY, J.-L. La déclosion: (deconstrucción del cristinismo, 1). Buenos Aires: Ediciones La Cebra, 2008.

KNAUER, P. Ontología relacional. In: QUEZADA DEL RÍO, J. (Coord.). Dios clemente y misericordioso. Enfoques antropológicos. Homenaje a Barbara Andrade. México D. F.: Universidad Iberoamericana, 2012. p. 19-41. 